\title{
PENERAPAN MODEL PEMBELAJARAN THINK PAIR SHARE (TPS) BERBASIS E-LEARNING UNTUK MENINGKATKAN KEMAMPUAN BERPIKIR KREATIF
}

\author{
Siti Khaulah ${ }^{1}$, Novianti ${ }^{1}$ \\ ${ }^{1}$ Universitas Al-Muslim, J1 Tengku Abdurrahman No 37 Matangglumpangdua Bireuen, 24261, Indonesia \\ E-mail: sitikh800@gmail.com \\ E-mail: novianti.idr@gmail.com
}

\begin{abstract}
Abstrak
Kurangnya pemahaman konsep -konsep khususnya mata kuliah perkembangan peserta didik mengakibatkan minimnya cara berfikir yang logis dan kritis . Sehingga tidak kritis dalam menghadapi permasalahan yang berhubungan dengan peserta didik dan lingkungan sekitar. Menindaklanjuti hal seperti ini, digunakan model pembelajaran Think Pair Share (TPS) untuk meningkatkan kemampuan berfikir kreatif. Selain pembelajaran secara kooperatif yang diterapkan pada penelitian ini, alternative lainnya dengan pengembangan e-learning. Pembelajaran Think Pair Share (TPS) berbasis E-Learning diterapkan dengan tujuan untuk meningkatkan pembelajaran, kemampuan berfikir kreatif dan hasil belajar mahasiswa. Penelitian ini merupakan penelitian kualitatif dengan menggunakan metode penelitian tindakan kelas dengan dua siklus pembelajaran. Dari hasil penelitian diperoleh terjadi nya peningkatan kemapuan berpikir kreatif siswa dan hasil belajar mahasiswa dari setiap siklus. Hasil belajar mahasiswa terjadi peningkatan sebanyak 23,81\%, dimana pada siklus I diperoleh $61,90 \%$ dan siklus II diperoleh $85,71 \%$. Begitu juga halnya peningkatan yang terjadi pada tingkat kreatifitas dan observasi aktivitas mahasiswa dan peneliti juga meningkat siklus I dan siklus II . Dengan demikian Penerapan model pembelajaran Think Pair share berbasis e-learning dapat meningkatkan kemampuan berfikir kreatif pada mata kuliah perkembangan peserta didik.
\end{abstract}

Kata Kunci: Think Pairs Share (TPS), E-Learning, Perkembangan Peserta Didik

\section{Abstract}

Lack of understanding of concepts, particularly subjects for student development, results in a lack of logical and critical ways of thinking. Thus, it is not critical in dealing with problems related to students and the surrounding environment. Following this up, Think Pair Share (TPS) learning models are used to improve the ability to think creatively. In addition to cooperative learning applied in this study, another alternative is the development of elearning. E-Learning based Think Pair Share (TPS) learning is implemented with the aim of improving learning, creative thinking abilities and student learning outcomes. This research is a qualitative study using a class action research method with two learning cycles. From the research results obtained an increase in students' creative thinking ability and student learning outcomes of each cycle. Student learning outcomes increased as much as $23,81 \%$, where in the first cycle $61.90 \%$ was obtained and the second cycle was $85.71 \%$. Likewise, the increase that occurred in the level of creativity and observation of the activities of students and researchers also increased cycle I and cycle II. Thus the application of Think Pair share learning models based on e-learning can improve the ability to think creatively in students' developmental subjects.

Keywords: Think Pairs Share (TPS), E-Learning, Student Development

\section{PENDAHULUAN}

Salah satu keberhasilan pada proses pembelajaran adalah bagaimana mahasiswa belajar dan tujuan utama belajar disertai dengan minat belajar mahasiswa. Mahasiswa - mahasiswa yang di didik saat ini merupakan calon guru masa depan, sehingga seorang calon guru wajib mngambil mata kuliah Perkembangan Peserta Didik. Perkembangan Peserta didik merupakan suatu komponen penting yang harus diketahui oleh seorang guru maupun calon guru. Seorang guru harus benar- benar memahami 
perkembangan peserta didiknya sendiri sehingga tujuan pembelajaran yang diinginkan tercapai dengan mendesain pembelajaran yang cocok dengan materi.

Pada umumnya, mata kuliah perkembangan peserta didik ini difokuskan pada kajian-kajian tentang tahap dan prinsip - prinsip perkembangan, baik perkembangan fisik, emosi, sosial, moral dan agama serta implikasi terhadap pendidikan dari tingakatan usia yang berbeda.

Berdasarkan hasil observasi dan wawancara dengan beberapa mahasiswa, dapat disimpulkan bahwa kurangnya pemahaman konsep- konsep yang telah diajarkan , apalagi disaat mahasiswa berfikir secara logis dan mengkaitkan pemikiran fakta dengan teori- teori yang telah ada. Begitu juga hasil wawancara dengan guru di Sekolah, apabila suatu pemebelajaran tidak memperhatikan perkembangan peserta didik nya maka akan membuat para muridnya bosan dan frustasi sehingga juga akan berdampak pada guru juga tertular rasa bosan dan frustasi ketika mengajar. Oleh karena itu, perkembangan peserta didik sangat diperlukan dalam setiap pembelajaran agar dapat memahami minat anak didik, psikologi anak, dan permasalahan -permasalahan yang terjadi diruang lingkup belajar.

Banyak langkah yang dilakukan agar suatu proses pembelajaran terlaksana sesuai dengan yang diinginkan, misalnya dengan menerapkan model - model pembelajaran yang disesuaikan dengan materi. Salah satunya adalah dengan menerapakan model pembelajaran Think Pair Share, dimana dengan model pembelajaran ini mahasiswa sangat membutuhkan pemikiran yang mengkaitkan fakta dengan konsep yang ada terutama tentang perkembangan peserta didik anak tersebut. Selain itu, memudahkan juga para mahasiswa dalam belajar dan mengingat apa yang telah dipelajari karena pada intinya pembelajaran ini akan didiskuskan didalam kelas setiap permasalahan yang ada.

Model pembelajaran Think-Pair-Share (TPS) adalah salah satu model pembelajaran kooperatif yang mampu mengubah asumsi bahwa metode resitasi dan diskusi perlu diselenggarakan dalam setting kelompok secara keseluruhan. Karakteristik model Think Pair Share (TPS) mahasiswa dibimbing secara mandiri, berpasangan, dan saling berbagi untuk menyelesaikan masalah. Pada penelitian ini menggunakan tipe Think-Pair-Share (TPS), karena pendekatan ini merupakan salah satu cara efektif dalam meningkatkan daya pikir mahasiswa, karena telah disusun sedemikian hingga dapat memberikan waktu yang lebih banyak kepada mahasiswa untuk berfikir. Hal in sesuai dengan pendapat Ibrahim, (dalam Mohammad Nur, 2005) “ TPS memeberikan waktu yang lebih banyak untuk berfikir, menjawab dan saling membantu satu sama lain. Prosedur yang digunakan dalam metode Think-Pair-Share (TPS) dapat memberi mahasiswa lebih banyak waktu untuk berfikir, untuk merespon dan saling membantu (Trianto, 2009).

Perkembangan zaman yang terus maju pada akhir - akhir ini, menuntut proses pembelajaran yang memanfaatkan internet dalam dunia pendidikan. Para pakar Teknologi Informasi telah banyak melakukan penelitian mengenai media yang dapat dimanfaatkan, salah satunya adalah pengembangan e-learning. E-learning ini dapat dijadikan salah satu tambahan media pembelajaran selain dengan pembelajaran kooperatif maupun konvensional. Sehingga menjadi alternative yang mudah apabila diaplikasikan dengan memanfaatkan jaringan wi-fi dan prosesnya dapat dilakukan dimana dan kapan saja.

Dari hasil paparan diatas, peneliti melakukan penelitian yang berjudul " Penerapan Model Pembelajaran Think Pair Share (Tps) Berbasis E-Learning Untuk Meningkatkan Kemampuan Berfikir Kreatif Dan Hasil Belajar Mahasiswa Pada Mata Kuliah Perkembangan Peserta Didik". 


\section{METODE PENELITIAN}

Pendekatan yang digunakan dalam penelitian ini adalah pendekatan kualitatif, Jenis penelitian ini merupakan jenis penelitian tindakan kelas (PTK) yang terdiri dari dua siklus. Menurut Mulyasa (2011:11) Penelitan Tindakan Kelas merupakan suatu upaya untuk mencermati kegiatan belajar sekelompok peserta didik dengan memberikan sebuah tindakan (Treatment) yang sengaja dimunculkan dengan maksud untuk memperbaiki dan meningkatkan kualitas pemebelajaran. Dalam Penelitian Tindakan Kelas terlihat adanya unjuk kerja mahasiswa sesuai pedoman tertulis yang diberikan oleh guru.

Adapun skema siklus penelitian tindakan kelas (PTK) menurut (Arikunto dkk, 2010:16) sebagai berikut:

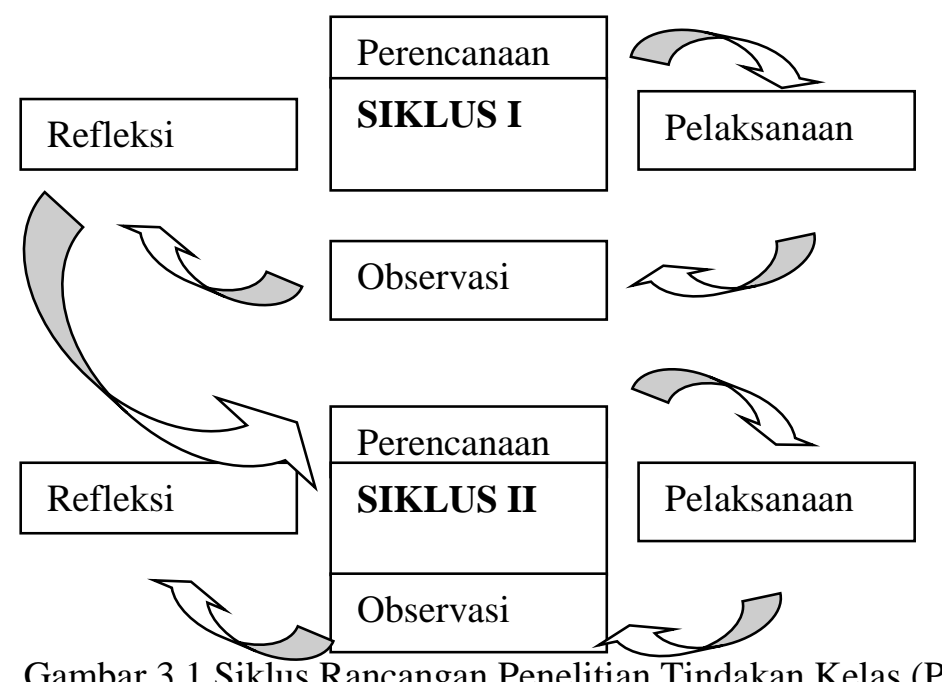

Gambar 3.1 Siklus Rancangan Penelitian Tindakan Kelas (PTK)

(Sumber: Arikunto, dkk, 2010:16)

Menurut Hopkins (dalam Wiriatmadja, 2005:11) mengemukakan bahwa: penelitian tindakan kelas adalah penelitian yang mengkombinasikan prosedur penelitian dengan tindakan substantif, suatu tindakan yang dilakukan dalam disiplin inkuiri, atau suatu usaha seseorang untuk memahami apa yang sedang terjadi, sambil terlibat dalam sebuah proses perbaikan dan perubahan.

Data yang dikumpulkan dalam penelitian ini adalah bersumber dari: 1) Nilai mahasiswa dalam mengerjakan soal-soal yang diberikan berupa tes awal, dan tes akhir setiap tindakan; 2) Wawancara dilakukan untuk menelusuri dan mengetahui hasil belajar mahasiswa, selain wawancara dilakukan untuk mengetahui respon terhadap pembelajaran yang telah diikuti; 3) Hasil observasi diperoleh berdasarkan lembar observasi yang diisi berdasarkan pengamatan teman sejawat dan dosen observer terhadap aktifitas peneliti dan mahasiswa yang dilakukan selama proses tindakan berlangsung; 4) Catatan lapangan selama proses pelaksanaan penelitian yang memuat kejadian atau fakta pada tempat berlangsungnya pembelajaran.

\section{Prosedur Pengumpulan Data}

Prosedur pengumpulan data yang digunakan dalam penelitian ini yaitu: 1) Tes yang dilakukan adalah tes awal dan tes akhir; 2) Wawancara dilakukan untuk menelusuri dan mengetahui pemahaman-pemahaman mahasiswa pada materi operasi matriks. Selain itu wawancara dilakukan untuk mengetahui respon terhadap pembelajaran yang telah diikuti; 3) Observasi dilakukan untuk mengamati aktivitas mahasiswa dikelas selama proses pembelajaran berlangsung; 4) Catatan 
Lapangan dilakukan untuk melengkapi data yang tidak termasuk dalam lembar observasi dan wawancara yang bersifat dalam kegiatan pembelajaran.

\section{Teknik Analisis Data}

Data terkumpul dalam penelitian ini dianalisis dengan menggunakan metode analisis data kualitatif yang mengacu pada pendapat Huberman (dalam Sugiyono, 2008: 246), yang mengatakan bahwa "Aktivitas dalam analisis data kualitatif dilakukan interaktif dan berlangsung terus menerus sampai tuntas, secara jenuh". Aktivitas dalam analisis data kualitatif meliputi: Reduksi data, Penyajian data dan Penarikan kesimpulan

Menurut Maidiyah (2008:26) "Dua segi yang dijadikan pegangan berhasil tidaknya tindakan yang diberikan, yaitu : kriteria proses dan kriteria hasil. Kriteria proses adalah jika hasil observasi telah mencapai skor $\geq 80 \%$. Sedangkan kriteria hasil adalah jika $\geq 80 \%$ mahasiswa mendapat skor $\geq$ 65 pada tes akhir tindakan".

Berdasarkan ketentuan diatas maka kriteria suatu tindakan dikatakan berhasil bila hasil observasi telah mencapai skor $\geq 80 \%$ dan kriteria hasil adalah jika $\geq 80 \%$ mahasiswa mencapai nilai $\geq 65$ pada tes akhir tindakan. Jika proses pembelajaran telah mencapai skor $\geq 80 \%$ tetapi hasil pelaksanaan pembelajaran belum mencapai $\geq 80 \%$ mahasiswa mendapat skor $\geq 65$, maka peneliti masuk ke siklus II dan merevisi kelemahan yang ada pada siklus I. Jika kriteria hasil pelaksanaan pembelajaran pada siklus I tercapai tetapi proses pembelajaran belum mencapai skor $\geq 80 \%$ maka peneliti mengulang tindakan I dan memperbaiki kelemahan yang ada.

\section{HASIL PENELITIAN DAN PEMBAHASAN Kriteria Tingkat Kreatifitas}

Kemampuan mahasiswa dari indikator-indikator berpikir kreatif yaitu berpikir lancar, berpikir luwes (fleksibel), berfikir orisinil, berpikir terperinci (elaborasi) dari hasil tes akhir tindakan siklus I mahasiswa berdasarkan tabel 4.4 diatas dapat diketahui bahwa presentase mahasiswa yang masuk kategori Sangat Kreatif adalah $\frac{3}{21} \times 100 \%=14,28 \%$ mahasiswa, kategori Kreatif adalah $\frac{5}{21} \times 100 \%=23,80 \%$ mahasiswa, kategori kurang kreatif adalah $\frac{6}{21} \times 100 \%=28,57 \%$ dan kategori Tidak Kreatif adalah $\frac{7}{21} \times 100 \%=33,33 \%$.

Sedangkan Skor persentase tingkat kreatifitas mahasiswa pada siklus II adalah yang masuk kategori Sangat Kreatif adalah $\frac{6}{21} \times 100 \%=28,57 \%$ mahasiswa, kategori Kreatif adalah $\frac{9}{21} \times 100 \%=42,85 \%$ mahasiswa, kategori kurang kreatif adalah $\frac{4}{21} \times 100 \%=19,04 \%$ dan kategori Tidak Kreatif adalah $\frac{2}{21} \times 100 \%=9,52 \%$.

Perbandingan Skor Persentase tingkat kreatifitas mahasiswa dapat dilihat pada diagram berikut. 


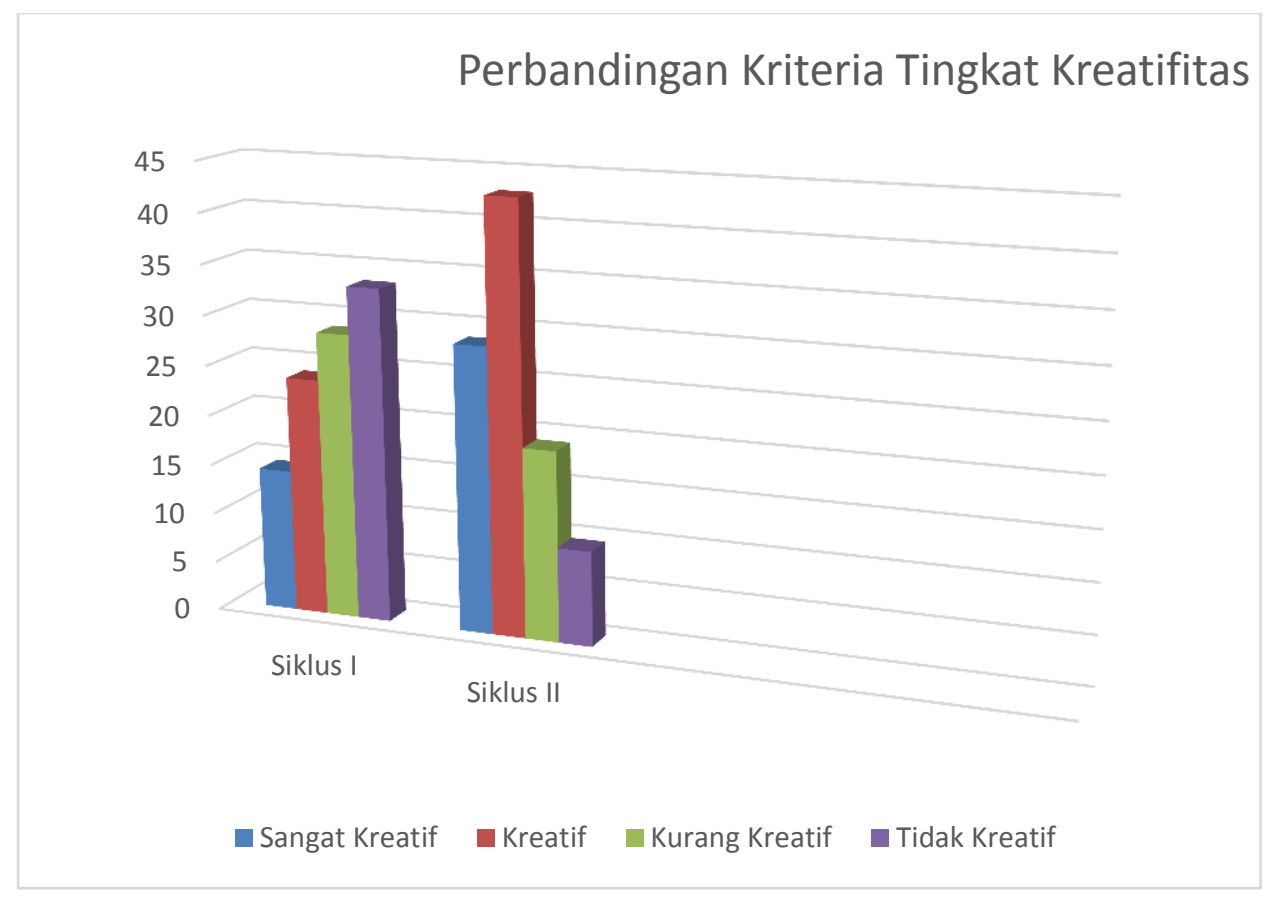

\section{Hasil Belajar Mahasiswa}

Pelaksanaan pembelajaran pada mata kuliah perkembangan peserta didik dengan Model pembelajaran yang digunakan pada siklus I ini adalah dengan menggunakan model pembelajaran Think Pair Share. Berdasarkan nilai tes akhir siklus I diperoleh data bahwa mahasiswa yang mendapat skor $<65$ sebanyak 8 orang mahasiswa dan yang mendapat skor $\geq 65$ adalah 13 orang mahasiswa. Setelah dihitung persentase maka keberhasilan ketuntasan tes akhir siklus I mencapai 61,90\% sedangkan yang tidak tuntas mencapa 38,09\%. Dengan demikian sesuai dengan kriteria yang ditetapkan pada siklus 1 yaitu $\geq 85 \%$ mahasiswa tidak mencapai nilai 65 maka siklus 1 belum berhasil, dikarenakan masih rendahnya kemampuan berbicara mahasiswa. Disebabkan sikap dan minat mahasiswa dalam berbicara masih rendah yang pada umumnya mahasiswa merasa takut dan malu saat ditugasi untuk tampil di depan. Adanya kesulitan mahasiswa dalam belajar kelompok karena kurang dapat berkomunikasi dengan teman sekelompoknya sehingga timbul masalah pada dirinya dalam belajar kelompok. untuk itu peneliti melakukan siklus II.

Sedangkan nilai tes akhir siklus II diperoleh data bahwa mahasiswa yang mendapat skor $<65$ sebanyak 3 orang mahasiswa dan yang mendapat skor $\geq 65$ adalah 18 orang mahasiswa. Setelah dihitung persentase maka ketuntasan tes akhir siklus II mencapai $85,71 \%$, sedangkan yang tidak tuntas mencapai $14,28 \%$. Dengan demikian sesuai dengan kriteria yang ditetapkan pada siklus II yaitu $\geq 85 \%$ mahasiswa sudah mencapai nilai 65 maka siklus II dikatakan sudah berhasil. 


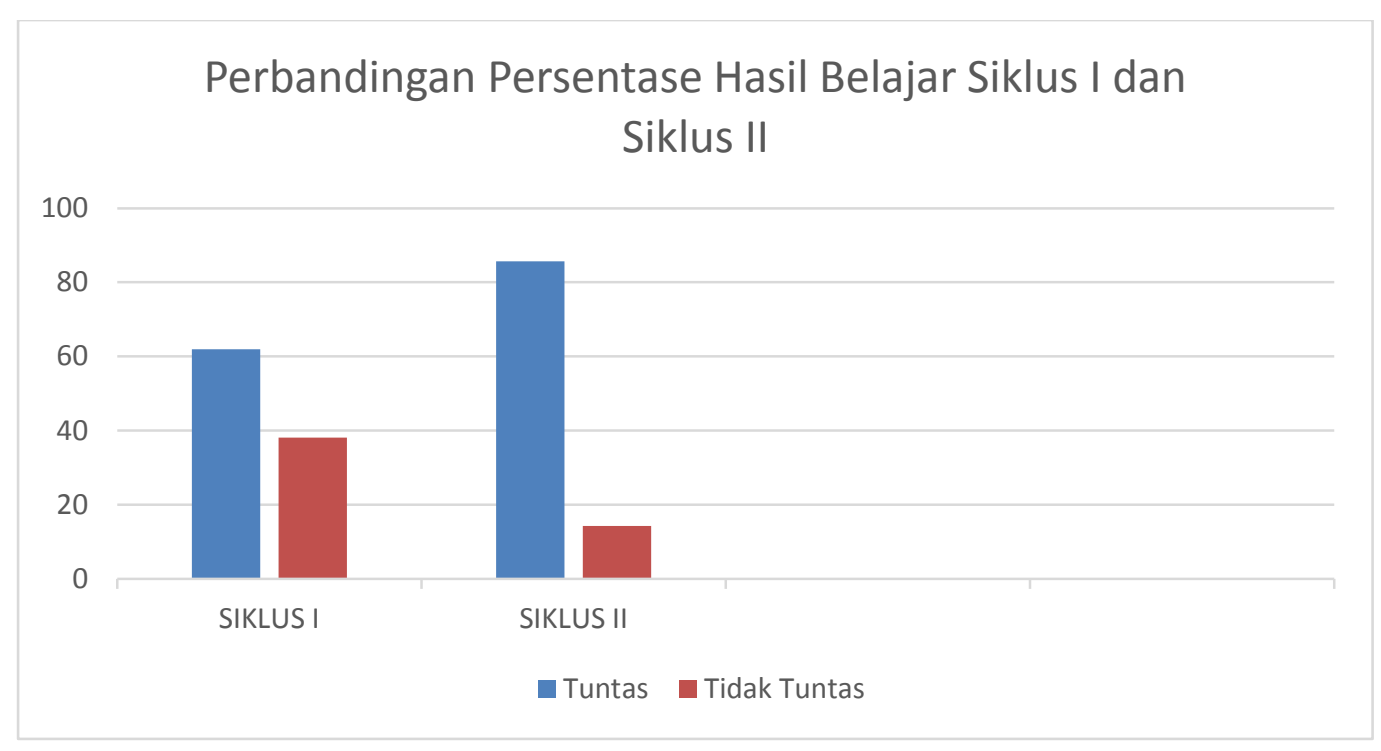

\section{Hasil Observasi}

Berdasarkan hasil observasi pengamat I memperoleh skor 49 dan pengamat II memperoleh skor 60, sedangkan jumlah skor maksimal 75 , kemudian jumlah skor dari masing-masing pengamat diubah dalam bentuk persen (\%) dengan menggunakan rumus (1). Dengan demikian persentase dari pengamat adalah: SP1 $=65,33 \%$ dan $\mathrm{SP} 2=80,00 \%$. Sedangkan skor persentase rata-rata adalah : SPP $=72,66 \%$. Dengan memperhatikan kriteria taraf keberhasilan pembelajaran terhadap pembelajaran terhadap aktivitas mahasiswa pada tindakan siklus I, observasi kedua pengamat termasuk kedalam kategori cukup baik. Hasil observasi terhadap aktivitas peneliti dan aktivitas mahasiswa, dapat disimpulkan bahwa aktivitas peneliti dalam mengajar sudah baik dan aktivitas mahasiswa dalam belajar masih cukup baik dan belum sesuai dengan yang direncanakan. Dengan demikian maka peneliti harus mengulang tindakan I dan memperbaiki kelemahan yang ada.

Sedangkan pada Siklus II pengamatan peneliti terhadap pelaksanaan kegiatan pembelajaran sudah terlaksana dengan baik. Hal ini terlihat dari antusiasnya para mahasiswa dalam mengikuti proses pembelajaran, baik itu dalam hal menanggapi pertanyaan pada saat peneliti menjelaskan materi, termotivasi dalam belajar kelompok, aktif saat berdiskusi dan presentasi. Hasil observasi pengamat I memperoleh skor 65 dan pengamat II memperoleh skor 72, sedangkan jumlah skor maksimal 75. Dengan demikian persentase dari pengamat adalah: SP1 $=86,66 \%$ dan SP2 $=96 \%$. Sedangkan skor persentase rata-rata adalah SPP $=91,33 \%$. Dengan memperhatikan kriteria taraf keberhasilan pembelajaran terhadap kegiatan mahasiswa dari hasil observasi dua orang pengamat, maka pembelajaran terhadap kegiatan mahasiswa sudah termasuk kategori baik. Dengan demikian dapat disimpulkan bahwa aktivitas peneliti dalam mengajar dan aktivitas mahasiswa dalam belajar telah sesuai yang direncanakan.

Perbandingan Persentase hasil Observasi pada siklus I dan Siklus II adalah: 


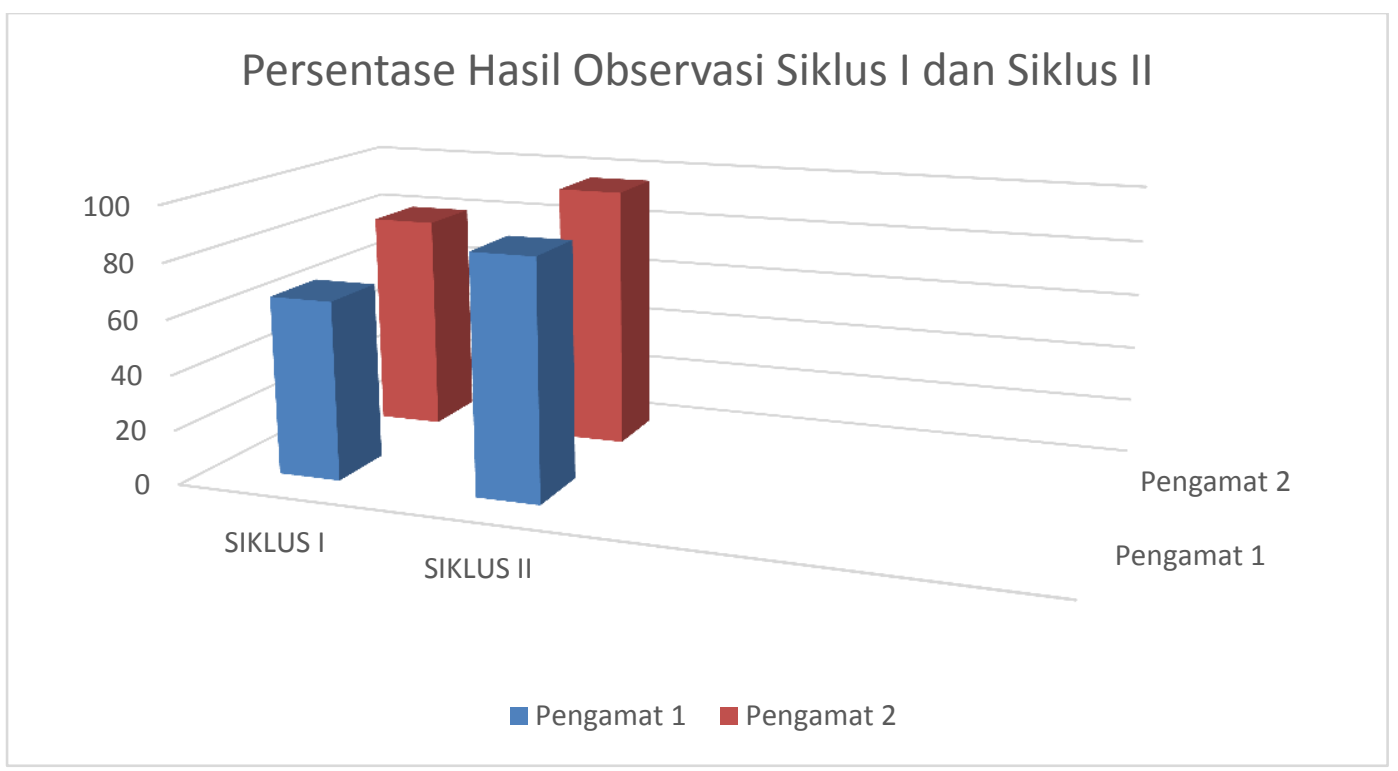

\section{Wawancara}

Berdasarkan hasil wawancara dengan 5 orang subjek wawancara, maka dapat disimpulkan bahwa mahasiswa senang belajar dengan model pembelajaran Think Pair Share (TPS) karena dapat bekerja sama dalam menyelesaikan tugas dan saling membantu satu sama lain dengan temannya terutama pada mata kuliah perkembanagn peserta didik. Pembelajaran terasa lebih menyenangkan dan mudah dipahami dengan mengeluarkan ide - ide kreatif pada mahasiswa. Sehingga dapat membuat siswa lebih aktif dan kreatif dalam menyelesaikan berbagai persoalan baik yang terjadi dilingkungan belajar maupun dilingkungan sekitar.

\section{Refleksi}

Adapun data-data yang diperoleh selama pelaksanaan siklus berlangsung adalah berdasarkan hasil observasi dua orang pengamat terhadap kegiatan peneliti dan aktivitas mahasiswa menunjukkan bahwa pembelajaran pada siklus I sudah berlansung dengan baik sesuai dengan yang direncanakan peneliti. Dari analisis data yang telah diuraikan diatas dapat disimpulkan bahwa pembelajaran siklus I belum berhasil. Peneliti melakukan atau pun merubah pola pembelajaran dan memperbaiki semua kekurangan yang ada pada siklus I sehingga pada siklus II dapat terlaksana dengan baik dan mencapai tujuan pembelajaran.

\section{KESIMPULAN}

Berdasarkan Hasil penelitian diatas, maka simpulan pada penelitian ini adalah sebagai berikut:

1. Pembelajaran dengan model Think Pair Share (TPS) berbasis e-learning dapat meningkatkan kemapuan berpikir kreatif siswa dan hasil belajar mahasiswa dalam memahami materi perkembangan peserta didik.

2. Pembelajaran dengan model Think Pair Share (TPS) berbasis e-learning dapat membuat siswa aktif dan kreatif dalam mengembangkan gagasan-gagasan atau ide-ide kreatif dalam menyelesaikan permasalahan yang terjadi dalm kehidupan sehari- hari.

Hasil observasi dua orang pengamat terhadap kegiatan peneliti dan aktivitas mahasiswa menunjukkan bahwa pembelajaran pada siklus II sudah berlansung dengan amat baik sesuai dengan yang direncanakan. 


\section{REFERENCES}

Darsono, M. (2000). Belajar dan Pembelajaran . Penerbit PT Rineka Cipta. Jakarta

Ibrahim, M. (2000). Pembelajaran Kooperatif. Surabaya. UNES

Maidiah, Erni. (2008). Penelitian Tindakan Kelas. Banda Aceh. FKIP. Universitas Syiah Kuala.

Mulyasa. (2011). Praktik Penelitian Tindakan Kelas. Bandung : PT. Remaja Rosdakarya.

Tarigan, Simson. (2010). Pengantar Metode Penelitian Ilmiah. Jurusan Kimia FMIPA. Unimed. Medan

Trianto. (2009). Mendesain Model Pembelajaran Inovatif Progresif : Konsep, Landasan dan Implementasinya pada Kurikulum Tingkat Satuan Pendidikan (KTSP). Kencana. Jakarta. 